\title{
Biology characteristic, abundance index and fishing aspect of donkey croaker (Pennahia anea Bloch, 1793) in the Tangerang Waters
}

\author{
Karsono Wagiyo ${ }^{1}$, Tirtadanu ${ }^{1}$, and Umi Chodriyah ${ }^{1}$ \\ ${ }^{1 *}$ Researcher at the Marine Fisheries Research Institute, Indonesia E-mail:k_giyo@yahoo.co.id \\ ${ }^{1}$ Researcher at the Marine Fisheries Research Institute, Indonesia
}

\begin{abstract}
Pennahia anea in Tangerang waters have a fork length between 9.4 and $23 \mathrm{~cm}$, with an average of $18.9 \mathrm{~cm}$ and modus $18-18.5 \mathrm{~cm}$. Growth type is isometric with correlation $\mathrm{R}^{2}=0.7266$ and $\mathrm{b}=3.2251$. The sex ratio of female: male $=1: 0.9$. Level and index maturity of gonad are highest in February and lowest in March.The length first maturity of donkey croaker at $15.8 \mathrm{cmFL}$. The length of the first capture ( $\mathrm{Lc}$ ) by danish seine net at 16,76 $\mathrm{cmFL}$ and by gill net at $17.60 \mathrm{cmFL}$. Asymptotic length $(\mathrm{L} \infty)$ at $23.89 \mathrm{cmFL}$ and growth rate $(\mathrm{K})=0.84$ per year. Mortality rate; total $(\mathrm{Z})=4.01$, natural $(\mathrm{M})=1.73 /$ year and by fishing $(\mathrm{F})=2.28 /$ year. Exploitation rate $(\mathrm{E})$ of donkey croaker fish is 0.57 . CPUE the smallest in July was $0.41 \mathrm{~kg} /$ trip/day, the largest was in June $9 \mathrm{~kg} /$ trip/day, averaging $3.3 \mathrm{~kg} /$ trip/day. The fishing season from July to January with its peak in November and the famine season occurs in February-June with a peak in February. The main fishing gear for catching donkey croaker fish in the Tangerang waters is the danish seine net. The highest production of donkey croaker fish in June.
\end{abstract}

\section{Introduction}

Donkey croaker (Pennahia anea) is one of five species in the genus Pennahia, a member of the Sciaenidae $[1,2]$. Donkey croaker is similar in various locations as other members in the Sciaenidae have similar morphological and synonym names [3]. Pennahia anea in the world of commerce is called a donkey croaker or greyfin croaker [2]. The name of the croaker is because it makes a hoarse noise which comes from the swimming bubble vibrations [4].

Donkey croaker was have a habitat in coastal waters on continental shelves with water depths reaching $60 \mathrm{~m}$ [1]. Donkey croaker is a tropical and subtropical fish with the main distribution area in the Indian Ocean in the geographical area of $29^{\circ} \mathrm{N}-10^{\circ} \mathrm{S}$ and $48-125^{\circ} \mathrm{E}$ [1]. Donkey croaker live, especially at the bottom of muddy and sandy waters near the coast [4].

Donkey croaker can be caught with a variety of fishing gear and is a fish trash/by catch [5,6]. Donkey croaker caught with gill nets and bottom longlines [7]. Donkey croaker is often predominantly at fish landings originating from muddy coastal fishing areas. In Muara Gembong (Bekasi-West Java) as a center for land-based fishing catches from the surrounding coastal waters, donkey croaker fish dominates the composition of landed fish [8]. In Florida donkey croaker fish are mostly caught in recreational and commercial fishing [4]. The ease of being caught with various fishing gear causes donkey croakers to be classified as vulnerable to 
exploitation, even in India [9] and in the northern South China Sea [6] conditions are overexploited and over capacity.

Donkey croaker are one of the demersal fish that have economic value $[2,3,5,10,11,12$, 13]. Its production since 1997 has fluctuated, towards 2015 it has increased by $27.5 \%$ with a weight of 6.081 metric tons [14]. Donkey croakers are marketed in fresh and salty form [1]. In Asia donkey croaker (Sciaenidae) is one of the favorite seafood ingredients in cooking, because of its soft and nutrient-rich taste [15].

Tangerang Sea waters cover 10\% of the total area of the Sea of Banten province with an area of $377.40 \mathrm{~km} 2$ [16]. The waters of the Tangerang Sea are shallow coastal waters that are influenced by the west monsoon winds in December-February and the east monsoon in JuneAugust.

In the Tangerang sea area there are 9,955 fishermen (37.2\% of the total Banten fishermen) who do fishing. The number of fishing gear operating in the Tangerang sea area covered $46.27 \%$ of the fishing units in the northern coast of Banten. The types of fishing gear that were dominant included in the small scale fishery category, among others danish seine nets and gill nets [17]. Tangerang sea area fish production has contributed $33 \%$ of the total sea fishing in Banten [16].

\section{Materials and Method}

\subsection{Sampling and Data Collection}

Data was collected in March-October 2016 at Suryabahari landing site - Tangerang. The fork length, weight and abundance index data were obtained by means of daily measurements by enumerators taken randomly from the population of fish landing units. Data on sex and gonad maturity were obtained from observations of fish taken proportionally. Production data and catch season index were obtained from Suryabahari landing site-Tangerang. Data on fishing gear and catching area were obtained through observation on fishing trips and interviews with fishermen and business groups with fishermen.

\subsection{Analysis Samples and Data}

Sample analysis included species identification, sex and maturity of the gonads which was carried out macroscopically. Gonadal maturity is divided into 5 levels [2] namely: Level I (immature), small translucent gonads resembling threads; Level II (developing), enlarged gonads appear orange and strong to touch; Level III (maturing), vascular gonads and strong to feel and oocyte visible; Level IV (ripe), vascular gonad, strong to be touched, oocytes are yellow and begin to separate in the form of granules. Level V (spent), the gonads small and more opague than immature.

Data analysis is intended to find out values; CPUE, season index, growth parameters and mortality rate. The abundance index/Catch per Unit effort (CPUE) is elaborated from the equation;

$$
\mathrm{CPUE}=\mathrm{Cw} / \mathrm{T}
$$

where $\mathrm{CPUE}=$ Catch per Unit Effort, $\mathrm{Cw}=$ Weight of catch, $\mathrm{T}=$ Trip catch .

$$
\text { Season Index }(\mathrm{IM})=\frac{1}{\mathrm{t}} \times \sum\left(\frac{\text { Montly production }}{\text { Montly average production }} \times 100\right)
$$

$\mathrm{t}=$ number of years. 
Growth parameters (K and $\mathrm{L} \infty)$ are determined through the Von Bertalanffy equation [18];

$$
\mathrm{Lt}=\mathrm{L} \infty\left(1-\mathrm{e}^{-\mathrm{K}(\mathrm{t}-\mathrm{to})}\right)
$$

where $\mathrm{Lt}=$ length of fish at age to- $\mathrm{t}(\mathrm{cm}), \mathrm{L} \infty=$ fish asymptotic length $(\mathrm{cm}), \mathrm{K}=$ fish growth rate.

Total mortality rate (Z) using the Pauly [19]:

$$
\operatorname{Ln} \mathrm{N} / \mathrm{t}=\mathrm{a}-\mathrm{Zt}
$$

where $\mathrm{N}=$ number of fish at time $\mathrm{t}, \mathrm{t}=$ time needed to grow a length class and $\mathrm{a}=$ catch converted to length

\section{Result}

\subsection{Length-Weight Structure}

The results of fork length and weight measurement during the study period were obtained 4,409 donkey croaker fish. The fork-length frequency distribution has a mode in the $18-18.5 \mathrm{cmFL}$ length class (Figure 1). The smallest fork length is $9.4 \mathrm{cmFL}$, the largest is $23 \mathrm{cmFL}$ with an average of $18.9 \mathrm{cmFL}$.

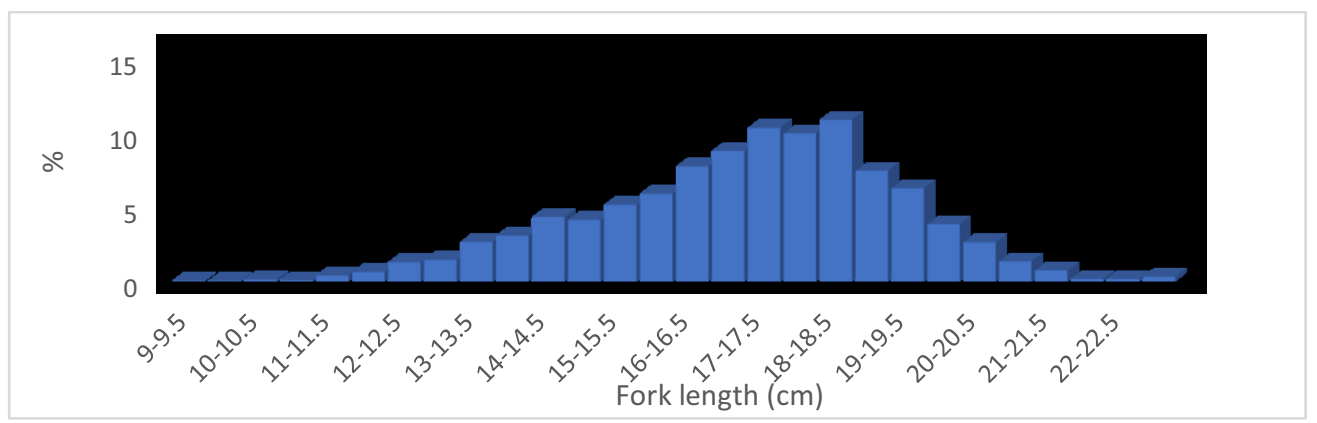

Fig. 1. Distribution of length frequencies of donkey croaker fish in Tangerang waters

The size of the weight of the donkey croaker fish was an average of $98.7 \mathrm{gr}$, the smallest, 44.9 gr, the largest, 188.6 gr. The length-weight relationship of donkey croaker fish (Pennahia anea) to show has a value of $\mathrm{b}=3.02251$ and $\mathrm{R}^{2}=0.7266$ (Figure 2 )

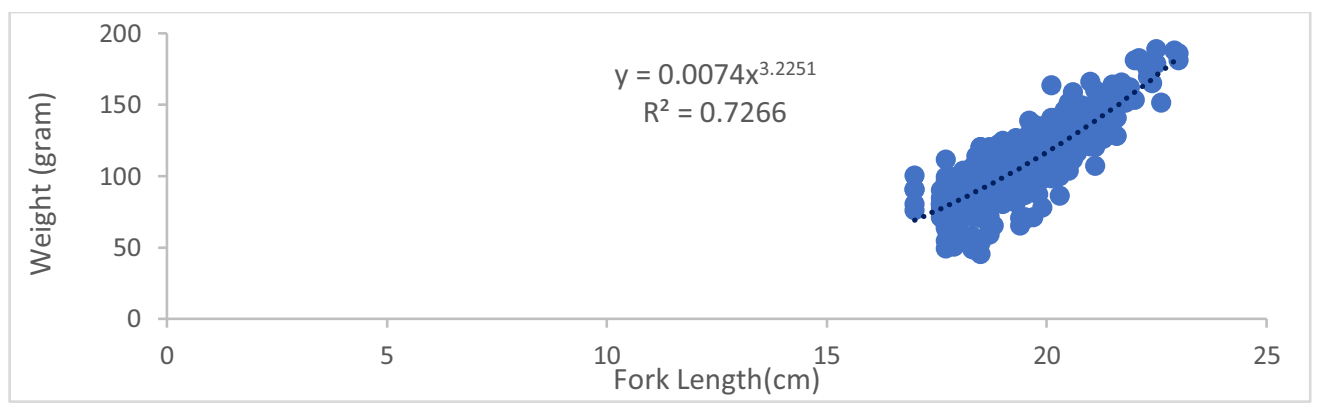

Fig. 2. The length-weight relationship of a donkey croaker fish 


\subsection{Sex Ratio}

The observations of the donkey croaker sex ratio have a female: male $=1: 0.9$ listed in Figure 3. In February the donkey crroaker sex ratio consisted of $59.72 \%$ females and $40.28 \%$ males. In March the sex ratio of donkey croaker fish all had a female: male ratio $=1: 9$ or $10 \%: 90 \%$. In May the sex ratio of donkey croaker fish had a female: male ratio $=1: 1.1$ or $43.86 \%$ : $56.14 \%$. In September the sex ratio of donkey croaker fish had a female: male ratio $=1: 0.4$ or $72.50 \%: 27.50 \%$. In October the sex ratio of donkey croaker fish had a female: male ratio $=$ 1.31 or $76.47 \%: 23.53 \%$.

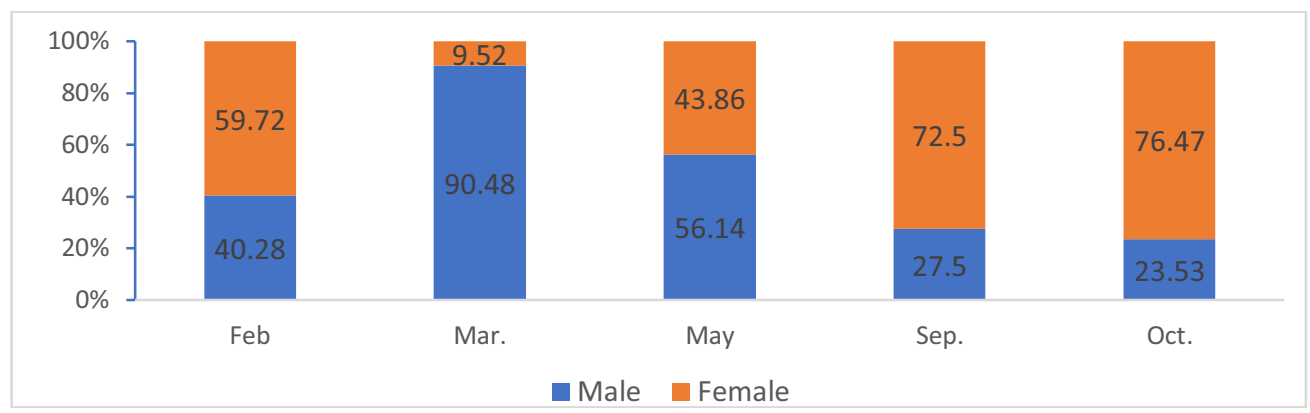

Fig. 3. The sex ratio of a donkey croaker fish in Tangerang waters

\subsection{Gonad Maturity Level (GML)}

The results of observations of the level of gonad maturity (GML) of donkey croaker fish are listed in Figure 4. The level of gonads maturity of donkey croaker in February, female consisted of $2.33 \%$ in the form of GML II and $97.67 \%$ in the form of GML III, the males consisted of $55.17 \%$ in the form GML II and $44.83 \%$ in the form of GML IV. The level of gonads maturity of donkey croaker in March, females has a composition; TKG II $50 \%$ and GML III 50\% and males have the composition of GML I 10.53\%, GML II 57.89\%, and GML III $31.58 \%$. In May the gonads maturity level of the donkey fish, female has a composition; GML I 4\%, GML II $3250 \%$ and GML III $64 \%$ and males have the composition of GML I $21.88 \%$ and GML II $78.13 \%$. The gonads maturity of the donkey croaker in May declined compared to observations in March. In September the level of gonads maturity of donkey croaker, female has composition; GML I 34.48\%, GML II $29.31 \%$ and GML III $36.21 \%$ and males had the composition of GML I 45.5\% and GML II 54.55\%. In October the level of gonads maturitys of donkey croaker female has composition; GML I 1.54\%, GML II 7.69\% and GML III $80.77 \%$ and males have the composition of GML I $12.5 \%$, GML II $62.5 \%$ and GML III 25\%. 


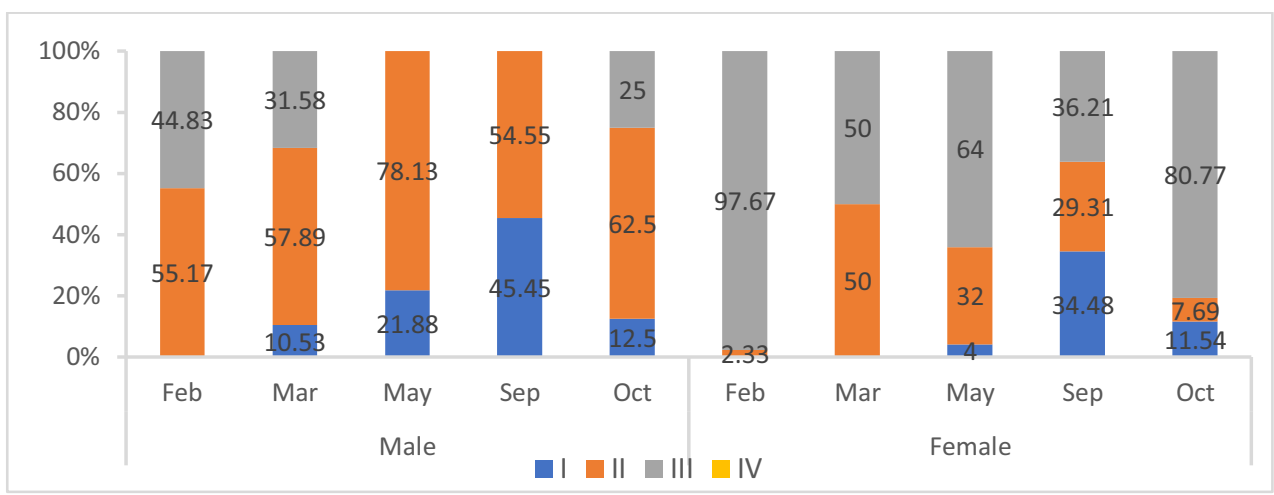

Fig. 4. The gonad maturity level of donkey croaker fish in Tangerang waters

\subsection{Gonad Maturity Index (GMI)}

The results of observations and calculations of the gonad maturity index of donkey croaker fish are listed in Figure 5. In March the gonad maturity index of female donkey croaker the smallest was 0.8 , the largest was 2.09 and the average was 1.45 , the male donkey croaker fish had the smallest GMI 0,33 , the biggest is 2.09 and the average is 0.73 . In May the gonad maturity index of female donkey croaker the smallest was 0.56 , the largest was 5.37 and the average was 1.76 , the male donkey croaker fish had the smallest GMI of 0.12 , the largest of 0.99 and an average of 0.41 . In September the gonad maturity index of female donkey croaker the smallest was 0.24 , the largest was 10.51 and the average was 1.94 , the male donkey croaker fish had the smallest GMI of 0.10 , the largest of 1.01 and an average of 0.52 . In October, the gonad maturity index of female donkey croaker the samllest was 0.89 , the largest was 8.23 and the average was 3.94, the male donkey croaker fish had the smallest GMI 0.70, the largest was 8.43 and the average was 1.79 .

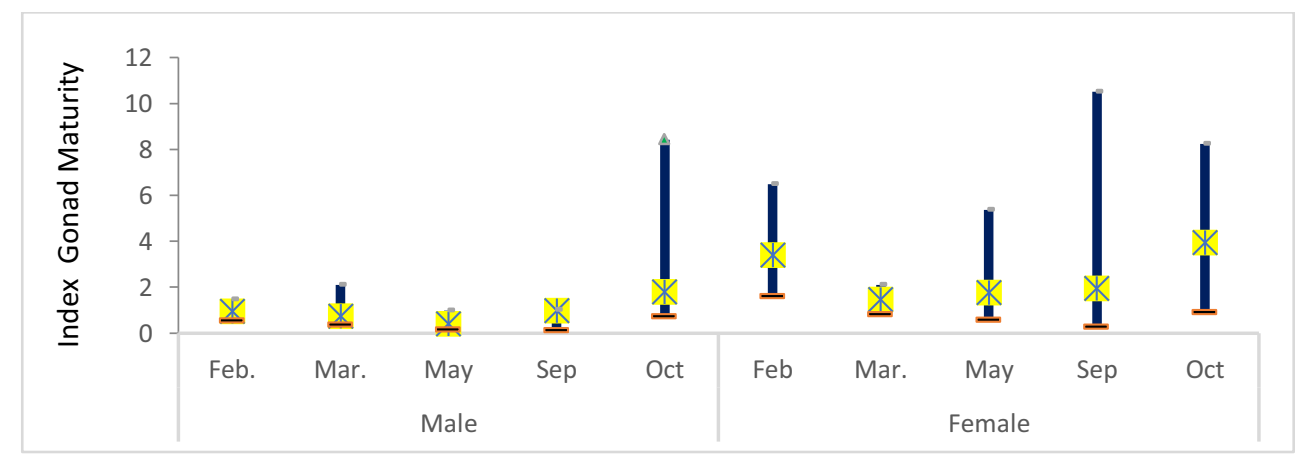

Fig. 5. The gonad maturity index for donkey croaker in Tangerang waters

\subsection{First Length Capture (Lc) and First Length Matured Gonad (Lm)}

Donkey croaker fish observed at the Suryabahari landing site were found to have the first length capture are $16.76 \mathrm{cmFL}$ by danish seine net (Figure 6a) and first capture by gill net are $17.60 \mathrm{cmFL}$ (Figure 6b). The size of the first gonads maturity of donkey croaker fish occurs at a length of $15.8 \mathrm{cmFL}$. 


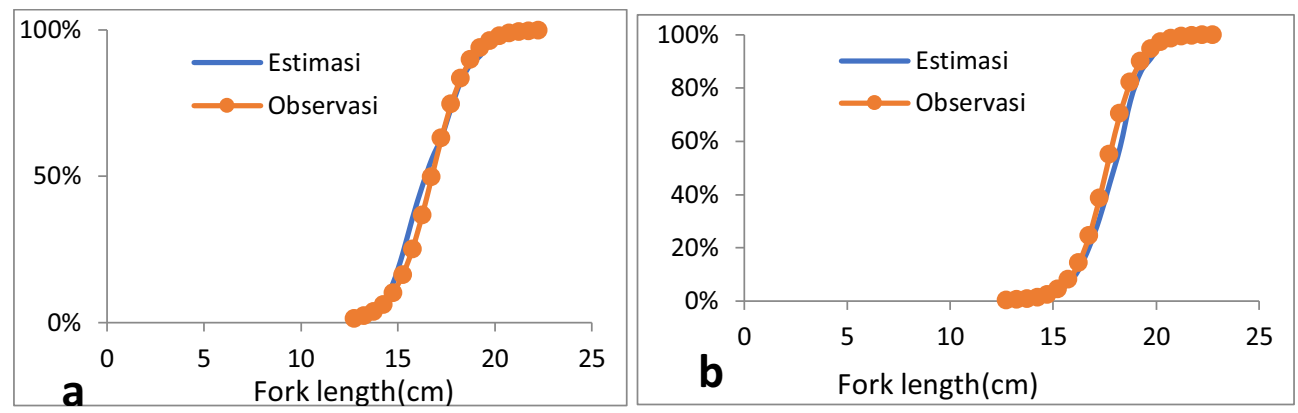

Fig. 6. The length first capture for donkey croaker fish; a) danish seine net and b) gill net in Tangerang waters

\subsection{Growth Rate}

Data of the length frequency of the donkey croaker fish in the Tangerang waters obtained different mode values according to the month of observation. Growth rates are obtained by tracking shift mode in time sequence. The lines that go through the most modes will describe the pattern of growth. By using the ELEFAN program an asymptotic length (L $\infty)$ of 23.89 $\mathrm{cmFL}$ and growth rate $(\mathrm{K})=0.84$ per year. The frequency distribution of fork length and growth curve for donkey croaker fish is presented in Figure 7.

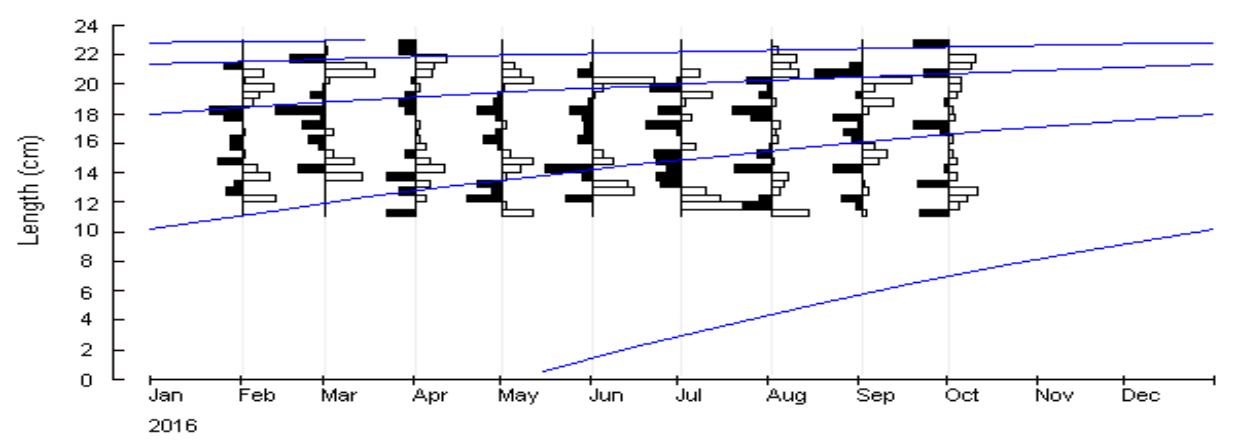

Fig. 7. The fork length distribution and growth line of donkey croaker fish in Tangerang waters

\section{7, Mortality and Exploitation Rate}

The total mortality rate $(Z)$ is estimated from the catch line curve that has been linearized using the growth parameters $K$ and $L \infty$. By using the ELEFAN program a graph of $Z=4.01$ is obtained as a slope as listed in Figure 8 . Natural mortality (M) calculated by the Pauly formula (1983) obtained a value of 1.73 / year. Therefore the fishing mortality (F) is 2.28 / year. The exploitation rate $(\mathrm{E})$ of donkey croaker fish is 0.57 


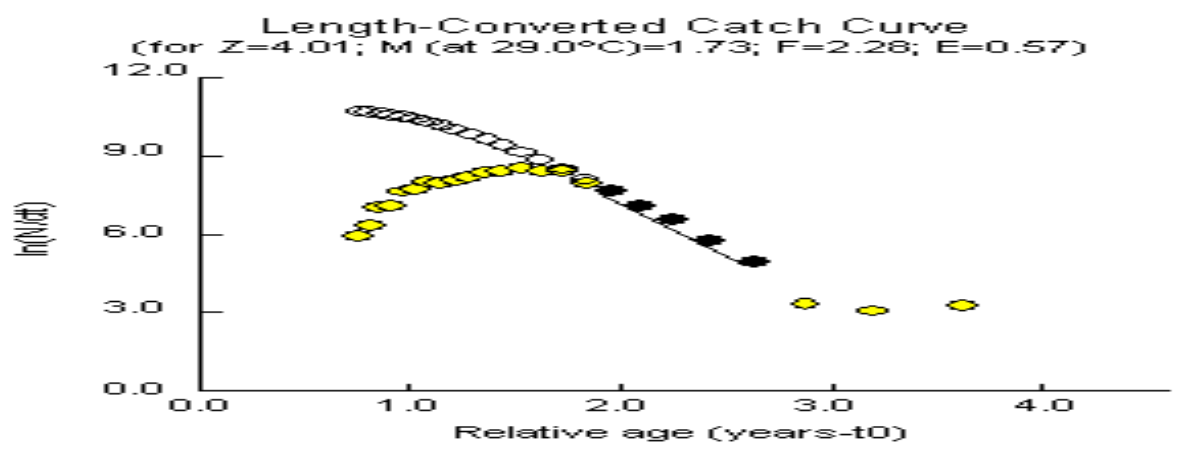

Fig. 8. Catch curve of donkey croaker based on fork length converted into relative age

\section{8, Abundance Index}

Extrapolation results from danish seine net catch data recorded by enumerators at the Suryabahari fish landing site obtained abundance index (Catch Per Unit Effort/ CPUE) of donkey croaker fish as shown in Figure 9. The smallest CPUE occurred in July $0.41 \mathrm{~kg} /$ trip/day, the largest occurred in the month June $9 \mathrm{~kg} /$ trip /day, an average of $3.3 \mathrm{~kg} /$ trip/day.

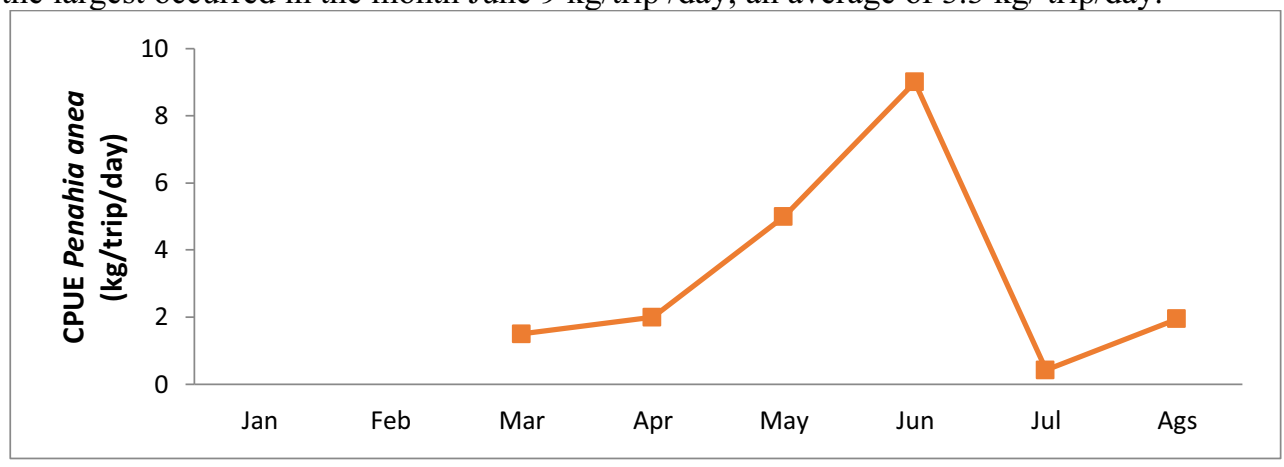

Fig. 9. Catch per unit effort (CPUE) of donkey croakear (Pennahia anea) in Tangerang waters

\subsection{Fishing Season}

Extrapolation results from production data in Suryabahari landing site obtained an index fishing season of donkey croaker in Figure 10. The fishing season of donkey croaker Tangerang waters occurred from April-November with a peak in June and a famine season in DecemberMarch with a peak at January.

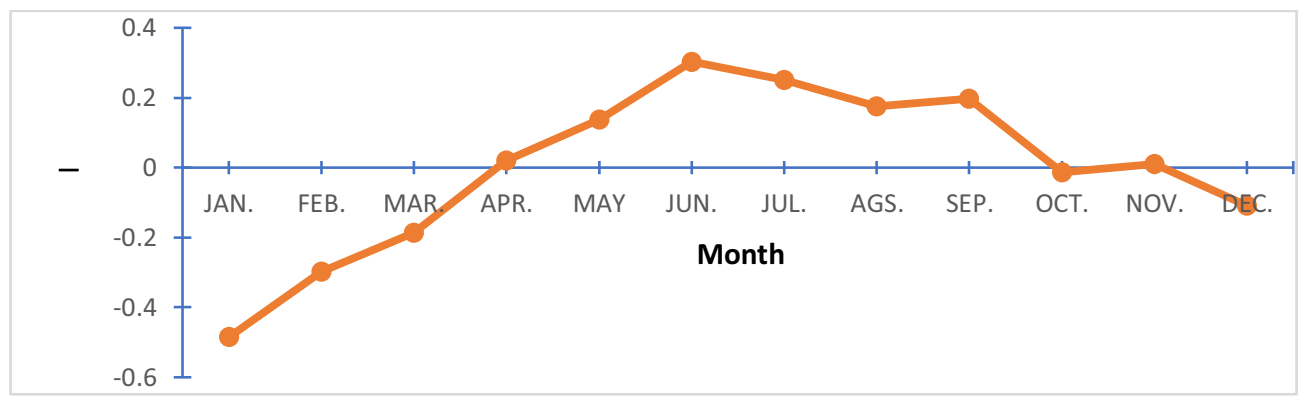


Fig. 10. Fishing season of donkey croaker fish in the Tangerang waters.

\subsection{Fishing Gears and Fishing Grounds}

The main fishing gear for catching donkey croaker fish in the Tangerang waters is the danish seine net and others gear similar. Other tools that can catch donkey croaker fish are gillnet . The main fishing ground of the donkey croaker fish is the same as the fishing ground of the Danish seine and gillnet, which is to the south of Lancang Island and the area between Damar island and Karawang cape.

\subsection{Production}

Based on data from Suryabahari landing site, records of monthly donkey croaker fish production are listed in Figure 11. The monthly donkey croaker production, the smallest occurred in January $1,877 \mathrm{~kg}$, the largest in June was $4,752 \mathrm{~kg}$ and the monthly average was $3,647 \mathrm{~kg}$.

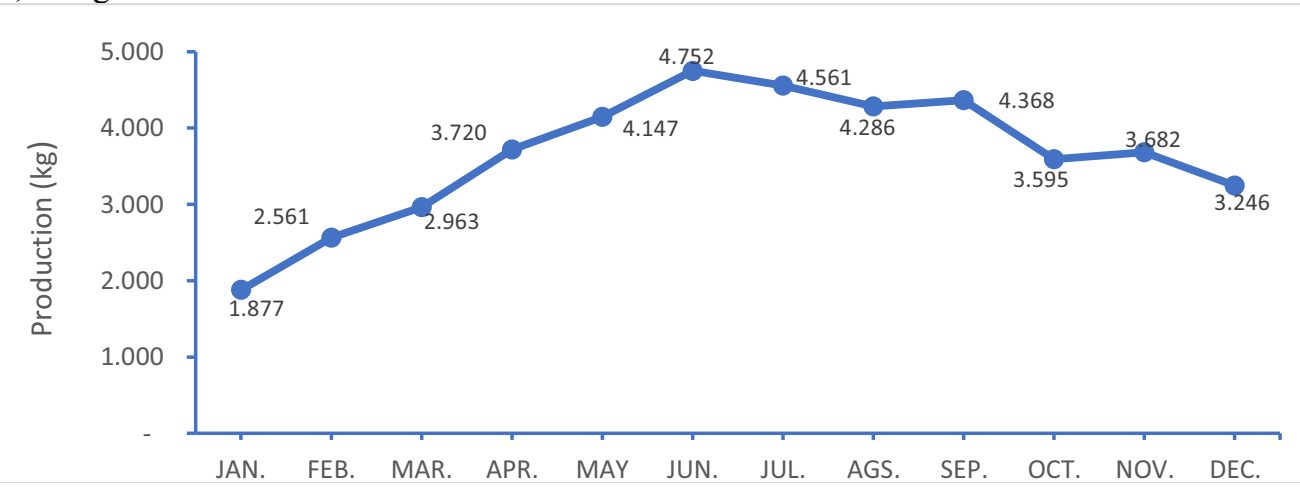

Fig. 11. Monthly production of donkey croaker fish in Suryabahari landing site

\section{DISCUSSION}

In this study analyzing the length-weight relationship because is a vital factor in the study of biology and fish stocks [20]. The length-weight relationship of donkey croaker fish in Tangerang waters shows isometric growth. Isometric growth types are also found in donkey croaker fish in Oman waters [21].

The average fork length of donkey croaker fish in Tangerang waters is $18.9 \mathrm{cmFL}$ greater than in Andhra Pradesh waters by $18.34 \mathrm{cmFL}$ [12]. This size is still greater than the minimum size that is permitted to be caught commercially at $13 \mathrm{cmTL}$ [22].

The sex ratio of donkey croaker fish in this study was females higher than males (1: 0.9). The phenomenon of females greater than males was found earlier with a ratio of $1.06: 1$ in the same waters [23]. The same phenomenon was found in studies in Andhra Pradesh waters-India with a ratio of 1.14: 1 [12] and in the China Sea with a ratio of 1.2: 1 [2].

Donkey croaker fish in Tangerang waters have a high percentage of mature gonads and a high gonad maturity index in February followed by a decrease both in the following month (March) and in the following month an increase in mature gonad and gonad maturity index up to October, so it can be expected that the peak spawning of donkey croaker fish occur in February-March. This happened related to the temperature rise in the waters of Tangerang waters from the previous season. The same spawning season was found in the waters of Andhra Pradesh-India [12]. Different spawning seasons are found in the South China Sea in May-June 
[2]. Even so donkey croaker in other months still do spawning in accordance with the statement [24] that donkey croaker fish spawn throughout the year (multispawner)

The first length of the gonads maturity $(\mathrm{Lm})$ of the donkey croaker in Tangerang waters has a value $=15.8 \mathrm{cmFL}$ which is not much different from $\mathrm{Lm}=14.3 \mathrm{cmSL}$ of the donkey croaker found in the northern part of the South China Sea [2]. The first length catch (Lc) of the donkey croaker fish by danish seine net has a value $=16.76 \mathrm{cmFL}$ and a $\mathrm{Lc}$ of gillnet $=17.60$. Lc of trawl at Palk bay are $9.7 \mathrm{~cm}$ [25]. Based on the value of the first length catch and the first length gonad maturity, catching with danish seine and gillnet for donkey croaker belong to the catch-worth category.

The growth rate of donkey croaker fish in Tangerang waters has a value of $\mathrm{K}=0.84$ faster than in Andhra Pradesh with a value of $\mathrm{K}=0.7 /$ year [12]. Conversely the infinity length $(\mathrm{L} \infty)$ $=23,89 \mathrm{cmFL}$ reached is shorter than that found in Andhra Pradesh-India with a value of $\mathrm{L} \infty$ $=33 \mathrm{cmFL}$ [12] and in Malaysia $\mathrm{L}_{\infty}=34.8 \mathrm{~cm}$ [26]. Donkey croaker in Tangerang waters with natural mortality rate $(\mathrm{M})=1.73$ year and fishing mortality rate $(\mathrm{F})=2.28 /$ year, respectively higher and lower than in Andhra Pradesh-India waters with $\mathrm{M}=1.35 /$ year and $\mathrm{F}=2.88$ [12]. The phenomenon of growth rate and natural mortality rate is high with the attainment of low infinity length, this can occur because the Tangerang waters are high productivity but at the same time polluted. Exploitation rate $(E)=0.57$ Optimum is still lower compared to India with $\mathrm{E}=0.68[12]$.

The catch per unit effort (CPUE) of donkey croaker fish by danish seine net in Tangerang waters varies monthly with an average of $3.3 \mathrm{~kg} /$ trip/day similar to catch rate an average of $0.55 \mathrm{~kg} /$ hour/ haul showing higher than in Andhra Pradesh 0.07-0.1 kg /hour/haul [12]. The difference in CPUE/catch rate is influenced by the environment, location and time [27].

The main fishing gear for donkey croaker fish in Tangerang waters is the danish seine net. Danish seine net resembles a trawl with the main goal of catching demersal fish[1]. Research in Indian waters found donkey croaker fish dominated the catch of the trawl [5, 28].

The fishing season for donkey croaker fish in the Tangerang waters from April to October differs from those in Cilacap waters which occurred in January-March [29]. Peak fish landing is different from the waters of Andhra Pradesh-India which occurred in January and September [2]. Differences in fishing season and peak landing of different fish between locations due to differences in seasons between locations. Catches fluctuate according to season [30]. Seasonal changes affect fish catches [9] Zacharia, et al., 2016).

\section{Conclusions}

The average size of donkey croaker fish landed from Tangerang waters is still larger than the minimum size allowed to be caught. Sex ratio of donkey croaker fish have a greater female than males. Peak spawning for donkey croaker fish occur in February-March. Donkey croaker in Tangerang waters has a high natural mortality and growth rate with a low infinity length. The exploitation rate towards moderate conditions with category high catch rate. Danish seine nets and gill nets fishing results in landing a donkey croaker fish with decent size. The fishing season lasts from April to September and peaks in June.

The data in this manuscript was collected in the context of a research activity titled "Stock Study of Fish Resources and Special Environments of the Jakarta Bay" held by the Marine Fisheries Research Institute in Fiscal Year 2016. Along with the completion of the preparation of this scientific paper the authors would like to thank their fellow employees Marine Fisheries Research Center and SuryabahariTangerang Fish Auction Place employees who have assisted in collecting data in this study.

\section{Reference}


1. Carpenter, K.E., \& Niem, V.H. The Living Marine Reources of the Western Central Pacific. Volume 5, Bony fishes part 3 (Menidae to Pomacentridae), (Food and Agriculture Organization of the United Nations, Rome, 2001)

2. Tuuli, C.D., deMitcheson, Y.S. \& Liu, M, Icthyological Research.Vol. 58 (4), 302-309 (2011) DOI 10.1007 / s10228-011-0228-0.

3. Li, W., Huang, H., Lin, X. \& Chen, B, Mitochondrial DNA Part B, 3: 2, 1180-1182 (2018) DOI: 10.1080 / 23802359.2018.1524719.

4. Herbinson, K.T., Allen, M.J. \& Moore, S.L, P.O. Box 800, Rosemead, CA 91770, 253264. (2000)

5. Mohan, R.S.L. A Review of the Sciaenid Fishery Resources of the Indian ocean. J, mar. biol. Ass India, 33 (1 \& 2): 134-145. (1991).

6. Greenpeace (2019), An Investigation Report into China's Marine Trash Fish Fisheries, Greenpeace EastAsia, URL : https: //secured-tatic.Greenpeace.org

7. Rashed, M., Hossain, M.A. \& Rahman, M.M, World Applied Sciences Journal 34 (10): 1297-1309. (2016).

8. Arsyad, G.K. Study of Jeni-Type of Fish Catched by Fishermen Based on Distance of Catch in Bahagia Beach, Muara Gembong District, Bekasi Regency, Thesis, Biology Education Study Program, Faculty of Teacher Training and Education, Pasundan University. Bandung (2017).

9. Zacharia PU, Dineshbabu AP, Thomas, S., Kizhakudan, SJ, Vivekanandan, E., Lakshmi Pillai, S., Sivadas, M., Ghosh, S., Ganga, U., Rajesh, KM, Nair, RJ, Najmudeen , TM, Koya, M., Chellappan, A., Gyanranjan Dash, G., Divipala, I., Akhilesh, KV, Muktha, M., Sen Dash, S. Relative vulnerability assessment of Indian marine fishes to climate change using impacts and adaptation attributes (ICAR,Central Marine Fisheries Research Institute, India 2016)

10. Pangsorn, S., Laong-Manee, P. \& Siriraksophon, S, Trend of Surimi Raw Materials, (Southeast Asian Fisheries Development Center, Fish People, 2007)

11. Khodadadi, M., Emami, F., Mohammadi, G. \& Riazi, S, Journal of Environmental Research and Development 4 (4), (2010).

12. Menon, M., Maheswarudu G., Rohit P., Laxmilatha P., Das, M. \& Rao K.N. (2015). Indian J. Fish. 62 (1) 46-51.

13. Al-Faisal, A.J. \& Absolute, F.M, Mesopo. Environ. j, 172-178 (2018).

14. Tridge (2019), Donkey Croaker Products, URL : https://www.tridge.com

15. Xu, D., Molina, W.F., Yano, C.F., Zhang, Y., de Oliveira, E.A., Lou, B. \& Cioffi, M.B, Molecular Cytogenetics, (2017) DOI 10.1186/s13039-017-0338-0. (2017).

16. Anonymous. The Profile of Maritime Affairs and Fisheries of Banten Province to Support Maritime and Fisheries Industry, (Center for Statistical Data and Information. , Marine and Fisheries Ministry, 2013)

17. Pujiastuti, D., Ernawati, R. \& Rahmawati, A, Journal of Fisheries and Marine 8 (1), 40 55 (2018)

18. Sparre, P. \&. Venema, S. C. Introduction to Tropical Fish Stock Assessment. Book 1: Manual. (Agricultural Research and Development Agency, Jakarta, 1992).

19. Pauly, D. A selection of simple methods for the assessment of tropical fish stocks, (FAO Fish, Romans, 1980)

20. Santhoshkumar, S., Rajagopalsamy, C.B.T., Jawahar, P. \& Francis, T, International Journal of Fisheries and Aquatic Studies; 1 (3), 9-11. (2014)

21. Sadr S.H.K, Valinassab, T. \& Shamsaie M, Renew Nat Resour Res. 2 (2), 14-24 (2011) 
22. Sivadas, M., Kizhaku, S.J. \& Sarada, P.T., Rathinam, A.M.M., Chandaprajnadarsini, E.M., Kumar, P.P.M. , Jagdis, I., Kavitha, M., Saravanan, R., Saleela, K. N., Surya, S. \& Laxmilatha, P, Mar. Fish Infor. Serv., T \& E Ser., 232, 3-6, (2017)

23. Tarigan, B.S. (2011). Samgeh fish reproductive biology study (Pennahia anea Bloch, in Jakarta Bay Waters, North Jakarta. Thesis, Bogor Agricultural Institute, (1793)

24. Waggy, G.L., Brown-Peterson, N.J. \& Peterson, M.S, Evaluation of the Reproductive Life History of the Sciaenidae in the Gulf of Mexico and Caribbean Sea: "Greater" versus "Lesser" Strategies. Gulf and Caribbean Fisheries Institute, 263-281 (2006)

25. Jayasankar, P. (1997) Population parameters of Pennahia anea and Nibea maculata in the Palk Bay/Gulf of Mannar area, India, Dragon, the ICLARM Quarterly, 20 (2), 46-48, URL : http://www.worldfishcenter.org

26. Jayasankar, P. (1995), Indian Journal of Marine Sciences 24, 153-157 (1995)

27. Yanli, T., Shuyang, M.A., Changdong, L., Xinmeng, W. \& Shasha, C, J. Ocean Univ. China 17: 973-982 (2018)

28. Maheswarudu, G., Rao, G.S., Rohit, P., Laxmilatha, P., Ghosh, S. \& Menon, M, Indian J. Fis., 60 (3), 27-33 (2013)

29. Saputra, S.W., Rudiyanti, S. \& Mahardhini, A. (2008), Saintek Journal of Fisheries Vol. 4, (1), $56-61$ (2008)

30. Chien, P.V., The, N.D. \& Quan, N.V, The Species Composition of the Croaker Fish (Family Sciaenidae) in the Coastal Zone of Quangninhandhaiphong Province. Proceedings of the Workshop Coastal Marine Biodiversity and Bio-Resources of Vietnam and Adjacent Areas to the South China Sea, Vietnam, 90-94 (2011) 